\title{
The General Features and Particular Characteristics of the Political Development of Abkhazia, Adygea, Dagestan and Chechnya in 1989-2000
}

\author{
Amina S. Khalilova* \\ Julia M. Lysenko \\ Gebek F. Gebekov \\ Abbaz D. Osmaev \\ Victor S. Lebedev \\ Astanda S. Khashba \\ Institute of History, Archeology and Ethnography, Daghestan Scientific Centre of Russian Academy of Sciences \\ Russian Federation; *Corresponding Email: kadja.ol@mail.ru
}

\author{
Doi:10.5901/mjss.2015.v6n6s7p123
}

\section{Abstract}

The issues related to the political developments in the period of 1989-2000 of government entities located in the Caucasus, is in the focus of today's historians, political scientists, sociologists, social scientists, and other scholars. The main objective of this study is to identify the general and particular features in the development of the political system of four Caucasian republics - Abkhazia, Adygea, Dagestan and Chechnya in the last decade of the XX century. The following material is based on an extensive review of the scientific literature, archival sources, legislation of the studied regions, periodicals, and the data from the Internet. Analysis of the data has enabled to give a general description and demonstrate the special features of both the political process, and the state structure in them. The revealed the reasons that contributed to the choice made by the studied regions in years 1989-2000 of the tactics and strategy of further political developments in the transformation of their social order. The study identified the main lines of development, and also shown the charactering features that emerged in each of the subjects, different ways of reaching an increase in public status and moved on to building a civil society based on democratic principles.

Keywords: political development, post-Soviet state-building, republican polity, Abkhazia, Adygea, Dagestan, Chechnya, military conflict, democracy, sovereignty

\section{Introduction}

At the present time research on the issues of political development of the state formations of the former Union of Soviet Socialist Republics (USSR), in particular the vicissitudes of becoming a democratic system in the Caucasus in 19892000 , becomes one of the important directions for the humanities and social sciences. This period is considered to be the most complex in terms of choosing the tactics and strategy of the future government, due to circumstances occuring on the entire territory of the USSR, the transformation of one social order to another and the drastically changed existing political order (Koposov, 2011; Adomanis, 2013; Souleimanov 2013). The republics of the Caucasus were not an exception, which in various forms and manifestations, was presented the 'parade of sovereignties'.

The search for self-identity, the reconstruction of the national idea, finding a new state in the 90-s of the twentieth century by the peoples inhabiting the region became one of the dominant factors in the life of the country. Authorities of the autonomous provinces, republics and regions demanded sovereign rights and political freedoms. Taking advantage of the crisis of the central government, 'the new regional elite' promised the radical changes to the people, putting into practice its right to control by means of armed conflict, demonstrations, strikes and coups. The democracy, which replaced communism, has led to the formation of new political relations between the emerged state entities. During this period, there was a redistribution of power, the formation of a new class of owners, the emergence of local elites, etc.

Talking about the relevance of the study, it should be noted that the present day social thought and science is pending huge resources on undertaking scientific works dedicated to the evidence of antiquity and uniqueness of each of the Caucasian ethnic groups. However, this does not lead to a genuine analysis and coverage of historical processes 
occurring in the region, does not reflect the characteristics of the interaction of neighboring nations. Given the fact that the preferences of the researchers on this historical period is given the problems associated with understanding the ethnopolitical conflicts, inter-confessional and inter-ethnic relations (e.g. see Ibragimov \& Matsuzato, 2005; Matsuzato \& Ibragimov, 2005; Kaliszewska \& Voell, 2015), it is extremely important to carry out an objective analysis of the methods of formation of a new political system, in almost all regions of the Caucasus. Due to the fact that some authors have neglected the principles of historicism and objectivism while undertaking their scientific work, since a significant part of such works is written by state order, the objective analysis of the reasons, background, progress and results of a conflict is replaced by elevation on the role (or even superiority) of authors' ethnic group over others (see: Akhmadov \& Magomedkhanov, 1995 Borov et al., 1999; Dzidzoev, 2000; Kuchiev \& Gerlik, 1989). The study of this kind has to carefully assess the arguments and facts cited by the warring parties, the researchers are facing an issue of scientific interpretation of the events of 1989-2000 in the Caucasus.

As it was mentioned, the processes that gripped the Soviet Union, Russia and, of course, the Caucasus were very diverse in its manifestations. This is what determines the choice of chronological and geographical scope of the study. Analysis of the main features of the folding state and political development of the state formations in the Caucasus has identified several basic models of these processes occurred, with each of the subjects having its own characteristics. In this regard, the most revealing are the following: Abkhazia, Adygea, Dagestan and Chechnya, where these features emerged quite clearly. The most common characteristic of these regions is their autonomous status, which made it a priority of the political development of the acquisition of sovereignty.

\section{Military Conflicts as a Model of Political Development}

During the collapse of the former Soviet state, one of the models of formation of a new political system was an armed confrontation. In most autonomous entities of the Caucasus, it took the form of international, mostly bilateral collision on the basis of the revival of the ideas of self-identity of ethnic groups who sought to concentrate power in their hands. In Abkhazia and Chechnya, the escalation of the conflict has reached the level of a coup d'etat - in one case ended with the emergence of a new non-recognized state, and in the other - a protracted civil war within the subject, which led to significant human and material losses.

\section{Abkhazia: The Autonomy of an Independent State}

The first of these republics in search of sovereignty was Abkhazia. In March 18, 1989 People's Forum of Abkhazia 'Aidgilara' (Unity) directs the union leadership 'Lykhni treatment' demanding the return to the Abkhaz Autonomous Socialist Republic (AbASSR) of a status of the Federal Socialist Republic (Avidzba, 2014, p.5.) by appealing to the fact that from 1921 to 1931 it had already been allied to the USSR. This 'treatment' was signed by 40 thousand people. Such a change in the status of the Abkhazian autonomy did not suit Georgia at all. Given the in the context of unfolding parade of sovereignties, the country's government did not respond to the appeal of the Abkhaz, wanting to keep the Georgian SSR in its structure.

Realizing that the Georgian authorities do not intend to peacefully release Abkhazia from its members, the government of AbASSR at the next meeting of the Supreme Council (SC) of the Republic on August 25, 1990 unilaterally announced the return of the status of SSR, adopting a decree "On the legal guarantees of statehood of Abkhazia" and the declaration "On the State Sovereignty of the Abkhaz Soviet Socialist Republic". This political act was the basis for the emergence in 1990-1994 of the precedent in the way of formation of a new political order in the autonomous regions studied. In response to this, the very next day the Presidium of the Georgian Supreme Council announced the declaration and resolutions adopted in Abkhazia as not valid. However, this was no longer perceived by the people of Abkhazia, and the abolition of the Constitution of Georgia in 1978 and return to the Basic Law of 1921, according to which Abkhazia was not included in its composition, legitimized the Abkhaz decree.

The next step of the AbASSR government was the resolution "On termination of the Constitution of the Abkhaz ASSR of 1978" adopted on July 23, 1991, in which the republic was returning to the Constitution of 1925 that declares: "Abkhazia - the sovereign state that holds state power independently..." (Central State Archive of the Republic of Abkhazia, p. I.23). This enabled the government of the autonomy to assign a country name - "Republic of Abkhazia", and take the coat of arms and a flag. As a result, the formation of a new state in Abkhazia has led to a major armed conflict, called - the Patriotic War of 1992-1993 with Georgia that wanted to preserve Abkhazia in its structure and leading to the formation of an independent state - Abkhazia, which raised its status from autonomy to the level of an independent country. 


\subsection{Chechnya: a military coup as a way to sovereignty}

Changes in Chechnya, as in other regions of the Caucasus began on 27 November 1990, when an extraordinary Session IV Supreme Council of the Chechen-Ingush Autonomous Soviet Socialist Republic (Chechen-Ingush ASSR) adopted a declaration "On the State Sovereignty of the Chechen-Ingush Republic" (Gakaev, 1999, p. 115). Its feature was the absence of references to the legislation of the USSR and the Russian Soviet Federative Socialist Republic (RSFSR), as well as introduction of a clause to art. 17 that the Chechen-Ingush Republic (CIR) will not sign an agreement with the Russian Federation (RF) until the territorial claims of the Ingush are not yet satisfied. So, the basis of the document on the independence of the republic initially pawned an unacceptable item for the federal government. But "any protests either from the Russian nor on the part of the allied authorities in Moscow did not happen" (Ibragimov, 2008, p.65).

The escalading governance crisis in the republic fell deeply in 1991 in an open confrontation between the army of $\mathrm{CIR}$ and the opposition-minded Executive Committee (EC) of the Congress of the Chechen people, led by D.M. Dudayev. The opposition has openly demanded for "the dissolution of the military force of CIR as having fulfilled its policy objectives and not conforming to the status of the Parliament of the new sovereign state" (Osmaev et al., 2015) that revealed the desire to change the government in the autonomy. Trying to remain at the helm, the head of the Supreme Council of CIR on March 11, 1991 has taken the decision not to participate in the All-Russian referendum. Retaining the pro-Russian orientation, the local authorities of Ingush area decide to hold this referendum, which marking the desire to withdraw from the Chechen-Ingush Republic.

Subsequently, the situation only worsened. Using the protest activity of the population, a group of General Dudayev at the II session of the Congress of the Chechen people, which took place on June 8-9, 1991 in Grozny, established a Joint Congress of the Chechen People (JCCR), which announced the overthrow of the existing government and the proclamation of the sovereign Chechen Republic "Nohchi-Cho" as not being a part of neither Russian or USSR. But not all members of the JCCR were willing to follow this path. Liberal part of IR, published a "Statement of 16 " managed to briefly stop the opposition and reduce the activity of the inhabitants of CIR. However, the events of August 1991 in Moscow gave a new impetus for rallies. Having gathered a rally at the square in Grozny on August 19, the Chechen opposition leaders condemned the coup and supported the President of the Russian Federation Boris Yeltsin. This not only gave them a kind of carte blanche, but also dragged on the sympathy of the population. And in September 1991, JCCR openly announced the dissolution of the Supreme Council of CIR. On September 15, during the visit of the Chairman of Supreme Soviet of RSFSR H. Khasbulatov this act was officially recognized, and the government responsibilities were temporarily given to the Supreme Council of Chechnya, headed by H. Ahmadov (Musaev, 1997). The first thing $\mathrm{H}$. Ahmadov and his supporters did on October 1, 1991 was announcement of the separation of CIR into two sovereign republics (Muzaev, 1997). Soon, however, some members of the Supreme Council decided to abandon this decision. Realizing that the situation could spiral out of control, D. Dudayev hold a military seizure of power in the country and on October 27, 1991 he declares the presidential and parliamentary elections in Chechnya (Ibragimov, 2008, p.733).

After virtually uncontested presidential elections in the Chechen Republic and the Parliament of the Republic, on November 1, 1991 D. Dudayev issued a decree "On the declaration of the sovereignty of the Chechen Republic". In response to these actions, the federal center on November 2 recognizes the "carried out in the Chechen-Ingush republic presidential elections and Supreme Council of the Republic as illegal and the undertaken acts as not enforceable" (On invalidating the elections...), and after 5 days, issued a decree of the President of the Russian Federation № 178 "On a state of emergency in the Chechen-Ingush Republic". On this basis, D.M. Dudayev was able to announce the intervention in the internal affairs of Chechnya and accused Russia in the beginning of the armed conflict. Also, to hold an official inauguration of the President of the Czech Republic on November 9, 1991, making himself the absolute head of the newly formed republic. Over the next few months, he urgently formed the main institutions of the new government: Parliament, the Council of the Constitutional Court and a new Constitution of the Czech Republic (Constitution of Chechen Republic of Ichkeria). These events have led to the formation of two sovereign republics of Ingushetia and Chechnya in 1993-1995 at the site of former Chechen-Ingush ASSR, as well as the beginning of future violent events, which stopped the Chechen peaceful development of democracy for nearly 10 years.

\section{The Transformation of the State System as a Path to Independence}

Significantly different path to sovereignty passed Adygea and Dagestan. Here, the struggle for power was exercised within the framework of strict observance of the rule of law, means of gradual transition from one structure to another. Perhaps the basis was the ethnic factor, i.e. actual mono-ethnicity of Adygeya and broadest multi-ethnicity of Dagestan 
coupled with the desire of the ruling elite of the republic to withdraw from the crisis peacefully.

\subsection{Adygea: from autonomous region to the sovereign Republic}

In order to improve its state status, on October 5, 1990 the government of Adygei Autonomous Region at the extraordinary session of Adygei Regional Council of People's Deputies converts into Adygei Autonomous Soviet Socialist Republic (AdASSR) by adopting, as in other subjects, the Declaration "On State Sovereignty of the Soviet Socialist Republic of Adygea" (Khalilova, 2012, p. 25). Later in the session of the regional Council of People's Deputies of June 28, 1991 it was approved, and after 5 days at a joint session of the Russian parliament adopted a law "On the transformation of the Adygei Autonomous Region in the Soviet Socialist Republic in the structure of RSFSR" (Mekulov, 1992, p.3 ).

In accordance with the changes that took place in 1991-1993 in the state system of the RSFSR: the appearance of the President institute therein, the use of the principle of equal representation of the republics in the formation of The Supreme Council of the Russian Federation, as well as the separation of powers in the country - in December 1991 in Adygeya held presidential elections, deputies of the Supreme Council of the Republic, formed the first parliament. At the first meetings of the Supreme Council of AdASSR approved the flag, emblem and anthem of the new republic. However, the ability to form a constitutional commission Adygea received only on April 21, 1992. The text of the Constitution of the Republic of Adygea (RA) was adopted at the XIV session of the Legislative Assembly (Khasa) on March 10, 1995. Note that the Basic Law of the Republic of Adygea directly connected it with Russia, emphasizing the status of the subject within the Federation.

\subsection{Dagestan: from communism to democracy}

On the way to sovereignty within Russia went Dagestan Autonomous Soviet Socialist Republic (DASSR). In line with the trends prevailing in the Caucasus, in Dagestan in 1991 at a meeting of the III Congress of People's Deputies DASSR it reviewed a draft of "Declaration of State Sovereignty", which was not accepted. Realizing the need to bring the status of the Republic in accordance with the requirements of time, government of Dagestan selected a transitional path. On May 13, 1991 the Supreme Council of the Republic adopts a Resolution "On the Statehood of the Dagestan ASSR" (Central State Archive of the Republic of Dagestan, I.45). Unlike the similar documents of other autonomies there was no mention of the state or national sovereignty (Ibragimov, 1998, p.7).

Instead of giving up the 1978 Constitution, the republican authorities only made some necessary amendments. Only the signing in December 1992 of the Union Treaty, by which the autonomy of the North Caucasus has received sovereign status within the Russian Federation, followed by March 30, 1993 "Federal agreement on the delimitation of powers..." (Constitution, 1993, p.71), being an integral part of the new Constitution of the Russian Federation, led to the need for a new Constitution of the Republic of Dagestan (RD). New Basic Law of Dagestan adopted on July 26, 1994 by Constitutional Assembly of the Republic of Dagestan was no longer an exact copy of the Constitution of the federal center (Constitution of RD, 1994).

A feature of the RD in terms of a state system in the 1990s was that the head of the republic became a collegial body - the State Council of Dagestan, instead of a popularly elected President. It included authoritative representatives of 14 titular nations of RD. Note that a similar experience in managing a republic not only was unique both in Russia and in the world, but was a natural response of the political elite to the challenges of time. Given that the political process in Dagestan that time gave rise to the lives of many prerequisites for the development of local democratic institutions, "parties, associations, popular movements, being created with the aim of coming to power, unwinding the federalization of the juridical personality of each of its (and their more than 70) peoples. Only such a body has been able to prevent armed conflict break out, carry out all the reforms in the framework of a policy based on tolerance, compromise and peacebuilding" (Magomedov, 2015, p. 8). Despite prevail in Dagestan in May 1998, the tendency to seize power (successfully implemented in other regions of the Caucasus), the State Council of Dagestan, headed by its chairman M.M. Magomedov for 1 day was able to lead the Dagestani society to agreement and direct the political development of the region in a peaceful way.

\section{Conclusion}

The analysis of the political situation in Abkhazia, Adygea, Dagestan and Chechnya in the period of 1989-2000 - a difficult period of transformation of the state system of the USSR and all its regions, allowed to identify two main ways of its development: the armed conflict and the peaceful transformation of the state. Among the features characteristic of the 
investigated republics are the fact that the three of them passed through a military confrontation in one way or another and got the same result as the $4^{\text {th }}$ republic, which is developing in line with the trends inherent to all the other subjects of the Soviet Union. Of course, the data suggested in the article should not be considered as complete, since there are much more particularities in the political development of the regions considered.

In general, the resulting material, which reflects the historical process of political formation of the republics under study shows that the basis of the described conflict lay emerging struggle of the elite for power in the subject, often covered with nationalist ideas. Practical results of the study can be used by the employees of ministries and departments, of both the studied republics and the Federal Center for the development of strategic and tactical plans for the development of these subjects and the whole region. Analysis of the sources and the literature suggests that despite all the difficulties that time, each of the subjects was able to find its own special path to becoming a democratic system, to form a legitimate government authorities and enter a new century, starting to develop a legal and civil society.

\section{Acknowledgment}

The study was funded by RHF project № 15-21-12001 «General and special in the socio-political development of Abkhazia, Adygea, Dagestan and Chechnya of the post-Soviet period: a comparative historical and legal analysis of the documentary".

\section{References}

Adomanis, M. (2013), Seven reasons that Russia is not the Soviet Union. Forbes. [Online] Available at: http://www.forbes.com/sites/ markadomanis/2013/12/31/7-reasons-that-russia-is-not-the-soviet-union/ (September, 2015)

Akhmadov, R., \& Magomedkhanov, R. (1995), Chechen tragedy. Moscow: Grail.

Avidzba, A.F. (2014), On political relations between Abkhazia and Georgia in pre-war period (1989-1992). War in the Caucasus - the lessons of history. Proceedings of the international scientific conference dedicated to the 20th anniversary of the Patriotic War of the Abkhaz Nation 1992-1993. Sukhumi: Printing House.

Borov, A.H., Dumanov, H.M., \& Kazharov, V.H. (1999), The modern state of Kabardino-Balkaria: background, ways of becoming, problems. Nalchik: El-F.

Central State Archive of the Republic of Abkhazia. F. 100. Op.1, D.30.

Central State Archive of the Republic of Dagestan. F. 352-R, Op.60. D.21.

Constitution of Chechen Republic of Ichkeria (1992), State News Agency of 'Chechen Press'. [Online] Available at: http://thechechen press.com/constitution (June 8, 2015)

Constitution of the Republic of Dagestan (1994), Business Law. [Online] Available at: http://www.businesspravo.ru/Docum/DocumShow DocumID_45311.html (August 28, 2015)

Constitution of the Russian Federation (1993). Moscow: Politizdat.

Declaration of State Sovereignty of the Abkhaz Soviet Socialist Republic (2012). Caucasian Knot. [Online] Available at: http://www.kavkaz-uzel.ru/articles/201925/ (March 12, 2015).

Declaration of State Sovereignty of the Chechen-Ingush Republic (2012). Chechen online library n.a. Pashkov Roman. [Online] Available at: http://chechenlaw.ru/?p=55 (May 20, 2015)

Dzidzoev, V.D. (2000), Caucasus of the late 20th century: the trend of ethno-political development. Vladikavkaz: SONTS.

Gakaev, D. (1999), The road to the Chechen revolution. Proceedings of the conference on "Chechnya and Russia: society and state", vol.3. Moscow: Polinform-Talburi.

Ibragimov, I.M. (2008), State-legal nature of the subject of the Russian Federation (on the example of the Republic of Dagestan). Abstract of the PhD thesis. Moscow.

Ibragimov, M.R., \& Matsuzato, K. (2005), Alien but loyal: reasons for the 'unstable stability' of Dagestan, an outpost of Slavic Eurasia. In: Matsuzato, K. (Ed.). Emerging Meso-Areas in the Former Socialist Countries: Histories Revived or Improvised. Japan: Hokkaido University, pp. 221-246

Kaliszewska, I., \& Voell, S. (2015), State and legal practice in the Caucasus: anthropological perspectives on law and politics. Dorchester: Ashgate Publishing.

Khalilova, A. (2012), The political, economic and cultural cooperation with the republics of Dagestan, Northern Caucasus in 1980-2000. Makhachkala: Aleph.

Koposov, N. (2011), The armored train of memory: the politics of history in post-Soviet Russia. USA: American historical association.

Kuchiev, A.G., \& Gerlik, I.Ts. (1989), Northern Ossetia: history and modernity. Ordzhonikidze: North Ossetian State University.

Magomedov, A.M. (2015), Dagestan: time of leadership of Magomedali Magomedov. Makhachkala: Doug Press

Matsuzato, K., \& Ibragimov, M.R. (2005), Islamic politics at the subregional level of Dagestan: tariqa brotherhoods, ethnicities, localism and the spiritual board. Europe-Asia Studies, 57 (5), 753-779.

Mekulov, D.H. (1992), Adygea on autonomy for sovereignty (1922-1992). Maikop: Adygknigoizdat.

Muzaev, T.M. (1997), Chechen Republic of Ichkeria. Political monitoring. [Online] Available at: http://www.igpi.ru/monitoring/10476 
45476/oct_97/chechen.html (June 14, 2015)

On a state of emergency in the Chechen-Ingush Republic (2010). Decree of the President of the RSFSR of 07.11.1991. number 178. Chechen national law. [Online] Available at: http://chechenlaw.ru/?p=88 (June 14, 2015)

On invalidating the elections held on October 27, 1991 in the Chechen-Ingush Republic. Resolution of the Congress of People's Deputies from the 02.11.1991. Collection of Laws. The legislation of the Russian Federation. Legal portal. [Online] Available at: http://sbornik-zakonov.ru/267739.html (June 14, 2015)

On the legal guarantees of statehood of Abkhazia. Caucasian Knot. [Online] Available at: http://www.kavkaz-uzel.ru/articles/17137/ (August 12, 2015).

Osmaev A.D., Lysenko J.M., \& Khalilova A.S. (2015), Political developments in Chechen-Ingush ASSR of 1989-1991. Modern problems of science and education, 1. [Online] Available at: www.science-education.ru/121-19435 (October 4, 2015).

Souleimanov, E. (2013), A wonderful country in the Caucasus: a brief history of Russian - Georgian relations in the pre-soviet era. International journal of Russian studies. 2 (1), [Online] Available at: http://www.ijors.net/issue2_1_2013/articles/souleimanov.html (October 10, 2015) 